Apuntes Universitarios, 2020: 10(4), octubre-diciembre

ISSN: 2304-0335 DOI:https://doi.org/10.17162/au.v10i4.515

\title{
Análisis y examen de modelos de explicación del proceso de formulación de políticas: un enfoque para el paradigma posmodernismo
}

\section{Analysis and examination of models of explanation of process of policy making: an approach to postmodernist paradigm}

\author{
Motahar Ebrahimi ${ }^{\text {1a }}$, Masoud Pourkiani ${ }^{2}$, Hossein Shariat ${ }^{3}$, Saeed Sayadi ${ }^{4}$, \\ Rostam Pour Rashidi ${ }^{5}$
}

Islamic Azad University, Kerman, Iran ${ }^{12345}$

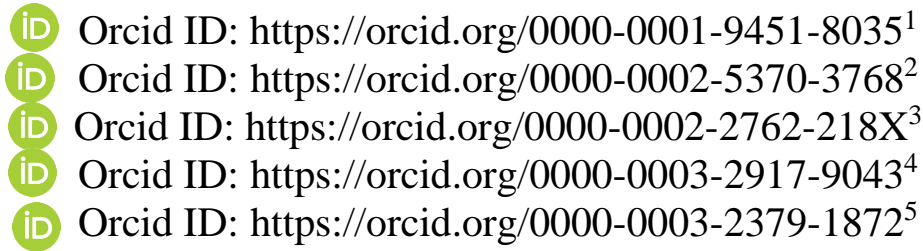

Recibido: 06 de febrero de 2020

Aceptado: 12 de agosto de 2020

\section{Resumen}

La posmodernidad ha cruzado las fronteras del arte y la filosofía muy rápidamente y al desafiar los fundamentos filosóficos de las ciencias sociales, ejerce una gran influencia en el dominio de la teorización de estos campos. En consecuencia, la ciencia de la formulación de políticas en general, y las teorías de formación de políticas en particular, no han permanecido inmunes a las doctrinas posmodernas. Dicho esto, el objetivo del presente ensayo es el análisis y examen de los modelos de explicación del proceso de formulación de políticas basados en un enfoque del paradigma posmodernista. Con este fin, se analizan los problemas de la racionalidad en la posmodernidad, la racionalidad en la formulación de políticas, y los enfoques que siguen varios tipos de racionalidad. Se esbozan los principales modelos de explicación del proceso de formulación de políticas que han llamado mucho la atención de los pensadores. Los estudios sugieren que nociones tales como la crítica de la objetividad, la racionalidad que se escapa, el superficialismo y la negación de origen y nociones como el mejoramiento, el desarrollo y la justicia, se encuentran entre las características del paradigma posmoderno que influyen en las ideas de formación de políticas. La influencia de las nociones antes mencionadas en el proceso de formulación de políticas debe considerarse como un recordatorio de temas como el modelo caótico en la formulación de políticas, los centros de poder, los grupos de presión, el mecanismo para incluir los temas marginales e insignificantes en la agenda, la falta de modelos universales y insistencia en modelos nacionales de desarrollo y toma de decisiones públicas, pluralismo y participación. 
Palabras clave: Postmodernismo, formulación de políticas, racionalidad, gobierno.

\begin{abstract}
Postmodernity has crossed the boundaries of art and philosophy very quickly, and by challenging the philosophical foundations of the social sciences, it has a great influence on mastering the theorizing of these fields. Consequently, the science of policymaking in general, and theories of policymaking in particular, have not remained immune to postmodern doctrines. Having said this, the objective of this essay is the analysis and examination of the models of explanation of the policy formulation process based on an approach of the postmodern paradigm. To this end, the issues of rationality in postmodernism, rationality in policymaking, and approaches that follow various types of rationality are discussed. The main models for explaining the policy-making process that have drawn much attention from thinkers are outlined. Studies suggest that notions such as objectivity criticism, escaping rationality, superficial, and negation of origin, and notions such as improvement, development, and justice, are among the characteristics of the postmodern paradigm that influence the policy formation ideas. The influence of the aforementioned notions in the policymaking process should be seen as a reminder of issues such as the chaotic model in policymaking, power centers, pressure groups, the mechanism for including marginal and insignificant issues on the agenda, the lack of universal models and insistence on national models of development and public decisionmaking, pluralism and participation.
\end{abstract}

Keywords: Postmodernism, Policy Making, Rationality, Government.

\title{
Introduction
}

Government, in its extensive sense by its order creating power, which is generated in the form of adoption and implementation of public policies, devotes itself to the regulation of social relations and organizes the social affairs. Thus, consciousness of the concept of public policy, mechanism of its making and framework of its implementation are considered to be among the primary necessities of the knowledge of government and society (Alvani \& Sharifzadeh, 2007).

The science of policy making struggles to expand our practical knowledge of the policies of public sector and recognize the governmental interventions in social affairs. In a nutshell, it speaks of the activities of public sector in macro form: i.e. which aspects of the public affairs are handled with the government? (Qolipur, 2010).

The study of the government in practice and the analysis of governments are of numerous complications, on the one hand, and the extensive development of the science of policy making in recent decades, the interdisciplinary nature of this science, different effects of policies in various domains, futurism of policy making, colorfulness of political aspects of it more than its technical aspects, require newer methodology, on the other hand. Countless efforts have been made in the domain of methodology and the 
struggle for reaching a method that leads to more trustable results have caused the process of policy making to be encountered with serious challenges. Insofar as addressing the needs of methodology requires the interpretation and finalization of some policies and even the interpretation of the processes and mechanisms (Daneshfard, 2009). One should accept that the paradigm of postmodernism has been replaced with the paradigm of modernism and the latter in its own time had been after separating itself from the past and tradition, because modernism was associated with the concept of development and its main emphasis was on intellectualism by the assistance of reason. Modernism was a consistent and uniform movement according to which determinacy of human reason was the only and superior subject of knowledge (Farahani, 2004).

Postmodernism as a great movement has immediately gone beyond the borders of art and philosophy and by challenging the foundations of the philosophy of social sciences influenced the theories developed in these fields. Accordingly, the science of policy making in general and the ideas of the formation of policy, in particular, have not remained immune from the postmodern doctrines. They are criticized based on the different ontological, epistemological and methodological requirements (Alvani \& Hashemian, 2008). Having said these, the goal of the present essay is the analysis of examination of the theories and models of explanation of the process of policy making based on the approach of paradigm of postmodernism.

\section{Methodology}

The present study is of the theoretical type and it is descriptive and analytic in view of its nature and the data have been collected via library studies. In other words, the required data are collected via the study of the relevant books and essays on the subject of research.

\section{Rationality in postmodernism}

Postmodernism is a crisis in modernism. It represents the crisis that has happened in the rational inferences and stability of modernity leading to the instability, temporariness, mobility, skepticism in postmodernism. The critique of postmodernism of modernism is concerned with two notions of crisis and self. Western self-confidence was one of the consequences of the belief in human rational force that never succeeded to explain the secret of crisis. The authoritarian aspect of the self-confidence lies in this incapability. Though Lyotard does not have any explanation for these crises, he insists 
on the efficiency of self and notes that it was the great narrator or main narrator whose narration now has come to its end. Postmodernism means the liberation of the evil of this narrator, narration or monologue (Angello, 2001).

Postmodernism, like enlightenment, is a complicated phenomenon. Depending on which aspect of this phenomenon is taken into account, it is easily praised or mocked. However, the essence of postmodernism is the denial of modern mind or reason's understanding of the categories of knowledge and truth. Modern mind believes that simple and uncomplicated truth, i.e. truth in its absolute sense, is the path of error and mistake. On the contrary, modern mind suggests that humans are intellectually capable and competent to consistently and precisely represent the aforementioned truth. Science and other manifestations of the self-subsisting independent reason are considered to be the means of the discovery of the ahistorical truth, i.e. the truth which is not dependent upon specific context or theme.

Reason and experience are regarded as the tool of decisive acquisition. By denial of this picture of epistemology, postmodernism presents the idea that the pictures of truth are different from the reality itself in the eyes of the observer and these pictures are always blurred. Some postmodern thinkers contend that the general and basic issue is that such words as truth and reality must be set aside, because these categories are an expression of an illusory and misleading object. Such words as truth and reality are even worse and more destructive than the useless vestiges of modern mind. In postmodern world, struggle for truth paves the ground for the useful readings, motivating interpretations, deconstructive program and bitter destructions. If we want to preserve the word "truth", we have to consider it in its particular form or meaning (Ewalt, 2001)

\section{Results}

\section{Rationality in policy making}

The policies that government (the administrative, legislative and judiciary forces) codifies are influences by different types of rationality. Snelen names four types of rationality that influence the government's policies: economic, political, legal and professional rationalities. Danaeifar by reviewing the literature of administrative management suggests that we can speak of two other types of rationality that govern human societies: moral and religious rationalities. Therefore, government's policies are influenced by various types of rationality (Figure 1). 


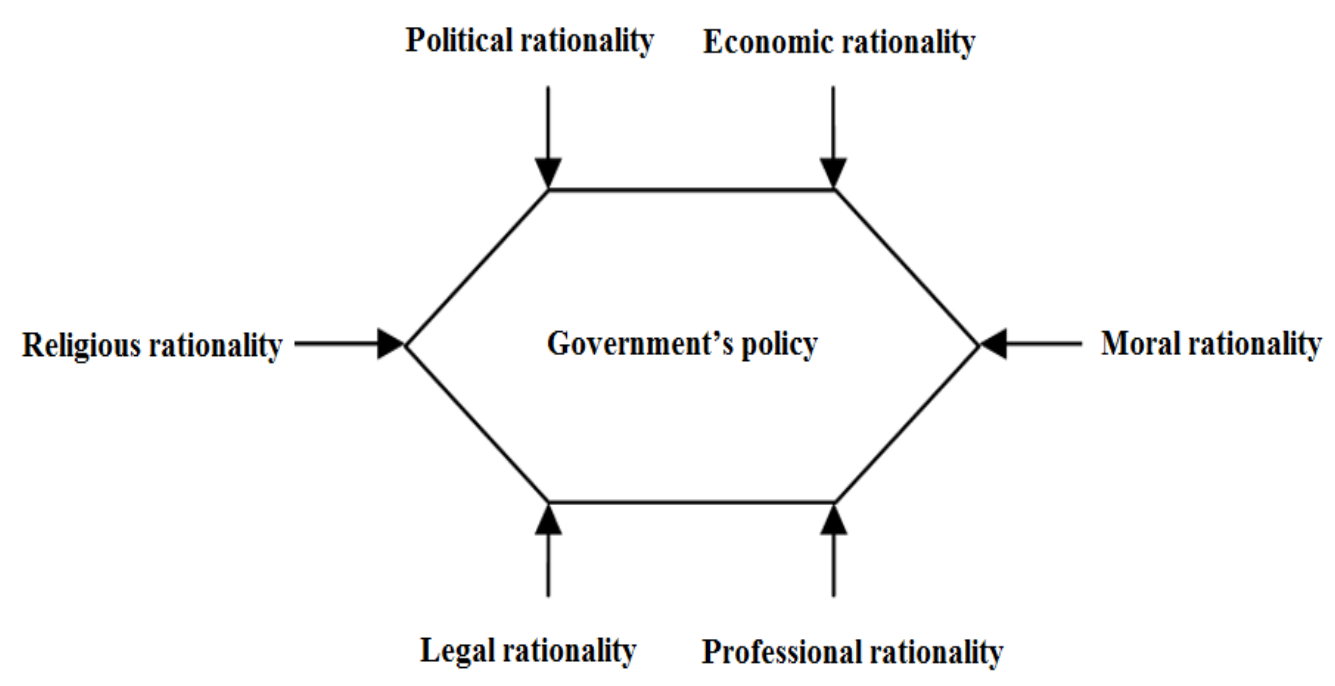

Figure 1. Rationalities Influecing Policies

\section{Approaches following from different types of rationality}

Managerial (Economic) Approach: In this approach, the science of values is at the hands of the managers and the organization is like a business. The management is a businessman and the person who refers to the organization is like a customer.

Legal Approach: The scope of action and freedom of action of management in public affairs are decided by the constitution, other mother laws, bills and regulations and the management in administrative sector is in charge of policies that have their own root in the constitution of every country.

Political Approach: In this approach, the organizational structure revolves around the political values, representation, accountability and responsibility. In this approach, representation and decision making are based on the public ideas and the significant beneficiaries and general opinions and media.

Professional Approach: Its main doctrine is the application of management of private sector to the governmental sector. The theory of public choice is a manifestation of the behavior of the governmental managers in this approach. Privatization begun in Iran since early years is an endorsement of this approach in our country's governmental sector.

Moral Approach: Existing differences in the dominant values of the governmental and 
private sectors are originated from this approach. Such values as justice, fairness, equality, sensitivity towards the citizens in governmental sector and efficiency are dominant values of the private sector.

Religious Approach: In this approach, servants are the lords of the political system. The organizational structure in it should be designed based on the principles of public satisfaction and divine satisfaction and every individual is God's servant and respected (Vahid \& Qalchi, 2007) (Figure 2).

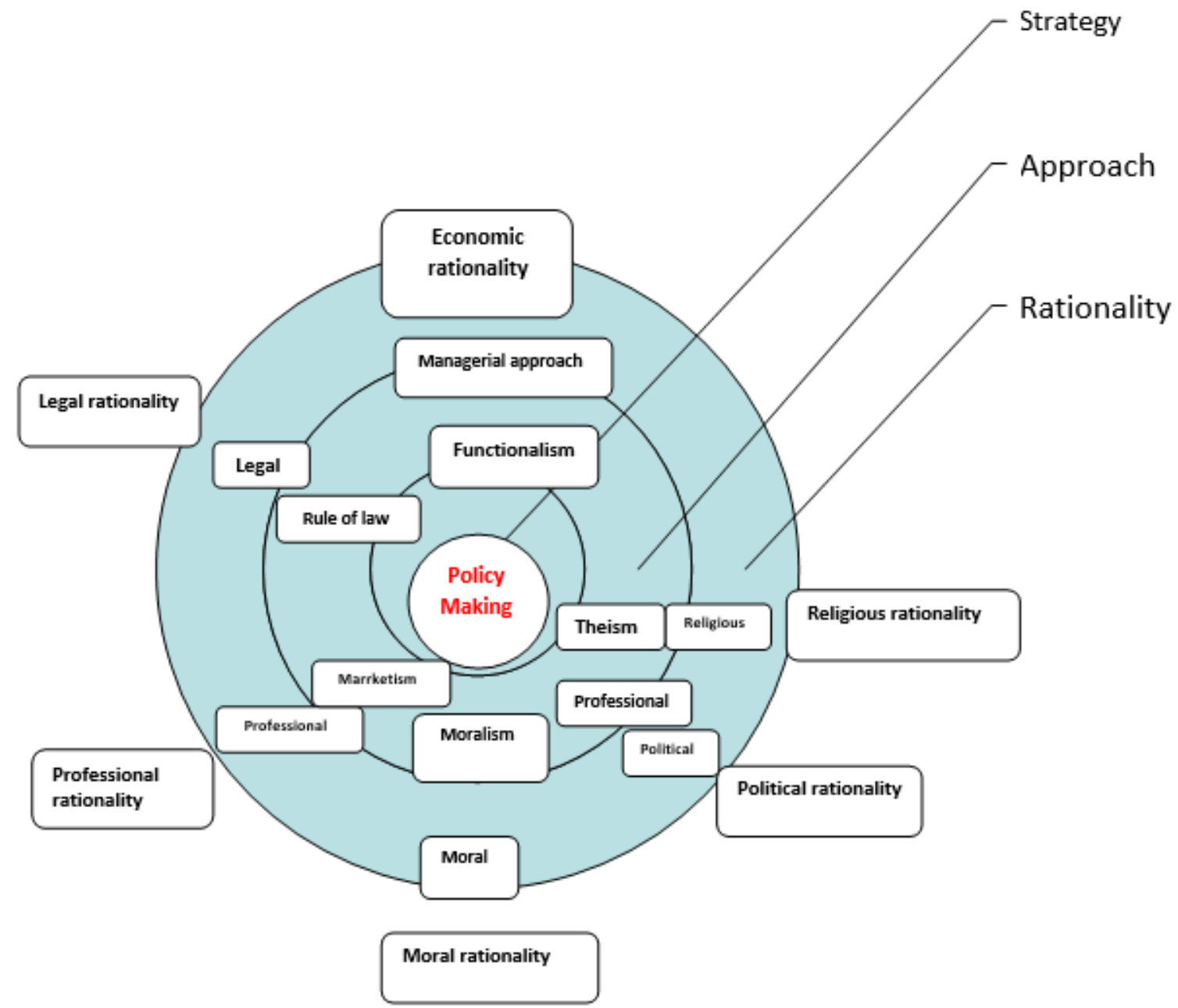

Figure 2. Relationship of Rationality, Approach, Strategy

\section{Policy making models}

\section{Discussion}

Different theories and models have been designed for explanation of the process of policy making. Given their increasing emergence and complication, it is impossible to discuss them in one single example in a detailed fashion. Therefore, we shortly discuss a number of the chief models that have been noticed more by the thinkers. 


\section{1- Absolute rationality or perfect rationality model}

Absolute rationality represents the rationalism of the economic man who is the counterpart of the social man. Economic man in every moment identifies his own preferences and pursues determinate and consistent goals. This model is grounded on three basic presumptions: first, access of the policy maker to all required information; second, explicit knowledge of preferences, desires and finally the policy maker's enjoyment of a holistic argument that allows him to study all possible solutions and their comparison (Vahid \& Qalchi, 2007). Policy making based on this model is faced with numerous barriers in practice. In other words, one can enumerate several barriers in response to the question why is the policy making not a rational process?

I. There are no determinate social values and goals upon which people would be unanimous. On the contrary, different and contradicted values govern the domain of policy making.

II. Many values and goals are not comparable and they cannot be distinctively evaluated.

III. Policy makers are not seeking after the maximization of the access to goals and they continue their efforts up to the moment when there is an "executable" path.

IV. Numerous investments on the process of plans and policies impedes the policy makers from the recognition of of other possible options.

V. There are numerous impediments in the path of collection of sufficient data for evaluation of all possible options and their results that include the costs of information collection, time and so on and so forth.

VI. The capabilities of prediction of sciences have not been sufficiently developed so that they can enable the policy makers for understanding the scope of the results and consequences of every single one of the options.

VII. Even with the developed techniques of computer analysis, the policy makers have not succeeded to acquire the required genius for the precise calculation of cost-benefit of numerous cultural, economic and political values and goals.

VIII. Lack of confidence regarding the results of the future policies forces the policy makers to keep with their previous policies as far as they can and in 
this way they reduce the probability of emergence of undesirable and unexpected results.

IX. The dissected nature of policy makers in extensive bureaucracies has made the interest of policy makers hard. Thus, ideas of each one of the officials of different sectors can hardly be united in one single decision (Dye, 2002).

\section{2- Satisfying model}

The criticisms of the existing radical perspective in the absolute rationality model have given rise to the effort for presentation of an alternative. Finally, the model of restricted rationality was offered by Herbert Simon (Simon, 2019). In this model, the decision maker examines the possible solutions but by finding a solution that is in line with the defined measures or even is not opposing and makes his own choice and he no longer continues until finding the best solution; the chosen solution is not the best rather the best solution among the existing examined solutions (Brooks \& Lewis, 2002).

The stages of policy making can be outlined based on the satisfying model as follows: identification of problem or definition of the goal, determination of the minimum standards which the options should be in line with, selection of the practical option that solves the problem, examination of its capability of solving the problem, determination of consistency of the solution with the minimum standards, implementation or change of policy (Guseh \& clayton, 2004).

\section{3- Incremental model}

The main hypotheses of this model consist of indeterminacy of the goals, interdependence of the definition of goals and analysis of situations. In other words, definition of goals is dependent upon the analysis of the existing conditions and it is not created in vacuum. Lindilum presents reasons for demonstration of the appropriateness of this model. Firstly, mistakes that are resulted from the incremental model do not have many negative effects on the environment given its conservative essence and can be easily reformed. From the point of view of policy, creation of consensus over the goals and preferences of this model is easier, because it does not give rise to more intensive opposition and sensitivity like the rationalist models. Then, it will be associated with further association. He continues that the Incremental Model is hard to define but it can provide more effective rational solutions for the problems of policy making (Vahid, 2006). 
This model has not been immune to criticism. One of these criticisms is the incapability of this model of presentation of a complete explanation of policies and decisions. This model does not offer a clear explanation of competitions of beneficiaries in the course of policy making which in the real world is an inseparable part of the process of policy making. It does not draw a clear line between the gradual changes and fast changes; this is to say that it does not clearly show the measures of incremental changes and fast changes. Moreover, this model does not provide an appropriate understanding of the clash of values and goals and the domination of the preferences of special elites in the moment of circulation of elites. It just provides a short explanation of what happens in ordinary conditions and non-sensitive decision making (Guseh \& Clayton, 2004). This model is criticized due to its insistence on partial changes and refusal of challenging the status quo even if it is wrong.

Another group believes that even in liberal democratic regimes, the power is not balanced, parallel and stable. The policy would be in the interest of a group which is in power and it would continue very slowly but by the change of elites a new policy that paves the path for the interests of the new group would be totally replaced with the previous ones (king \& Kraemer, 2007).

\section{4- Process model}

The implementation of policy making does not take place in a specific time and as an independent action. Rather policy making constitutes a process that includes several activities and stages (Gupta, 2001). In other words, numerous factors and policy makers play basic roles. They undertake different tasks in lien with the accomplishment of the process of policy making. In short, process of policy making can be regarded as a series of activities in the form of the stages of identification, problem, preparation of solutions, legalization, implementation and evaluation (Alvani \& Sharifzadeh, 2007).

Given the aforementioned approach, it is not the content of the policy that should be studied rather those processes should be examined according to which the public policies are developed, implemented and transformed (Alvani \& Sharifzadeh, 2007). Each one of the scholars in the field of public policy making have determined some stages for adoption of policy that these stages regardless of their partial differences are in general consistent with each other and in the section of the problem statement they are mentioned. 


\section{5- Garbage can model}

This model was first designed by Cohen, March and Olsen. By this model, they sought to describe the decision making in very unclear and chaotic conditions. This model was indeed a reaction to rational and political models that according to Cohen and his colleagues, lack the sufficient capability for making a decision in the contemporary complicated instable and ambiguous world (Alvani \& Sharifzadeh, 2007). Based on this model, which is referred to by Cohen and his colleagues as "organized anarchy", all types of rationalism are doubted in decision making (Vahid, 2001). Therefore, complication is not the only feature of policy rather we have to add ambiguity to it too. In this regard, March adds the following four categories:

1- Ambiguity in preferences and intentions: preferences and intentions are not permanent, stable and coordinated rather they change with the action.

2- Ambiguity in decision is not merely based on the technical measures rather it has symbolic aspects and is under the influence of myths and rituals.

3- Ambiguity in the interpretation of past: The past of organizations as well as their structure and goals are usually revised and reinterpreted based on the current conditions.

4- Ambiguity in purposefulness and relevance of actions, behaviors and decisions: one cannot see any clear relationship between solutions, problems, tools, goals, causes and effects (Angello, 2001).

\section{6- Institutional model}

Political activities are focused on the governmental institutions like the triple forces of the legislative, the administrative and the judiciary as well as the local organizations and municipalities. From a legal point of view, public policy is determined, implemented and applied through these institutions (Qolipur, 2018). There is a very close relationship between public policy and governmental institutions. A policy is exactly called public when it is implemented and applied by a number of governmental institutions. Adoption of policy by governmental institutions has several features. Before anything else, the government legitimizes policies. Verily this capability of government causes the policies to have sanctions and the citizens to follow them (Lester \& Stuart, 2003).

The other feature is extension and inclusiveness of public policies which are 
notified and exercised by the government. Leading the administrative power, the government implements the adopted policies throughout the society. While there is no such capability in other social institutions (Gerston, 2017). Despite the limited perspective of political sciences of the institutional studies in past, this method should not be considered a less important pattern (Lester \& Stuart, 2003).

Governmental constitution uses the organized patterns of behaviors of individuals and groups. The term "organized" in this context refers to those behavioral patterns that have a determinate order and continue to be in long term. These stable patterns of individual and group behaviors would influence the content of public policy. The institutions would be so organized that facilitate the implementation of a policy and create certain impediments before the implementation of other policy. These policies might give priority to some determinate interests in the society.

While others are deprived of its benefit, determinate individuals and groups would enjoy further access to governmental possibilities under determinate structural conditions as compared to other structural features. To put it in a nutshell, structure of governmental institutions might have an active and decisive role both in adoption and implementation of a policy (Howlett \& Ramesh, 2003).

\section{7- Systematic model}

Policy making in the form of a system is the result of environmental data and a current that provides certain solutions in the form of a policy based on the received problems (Qolipur, 2018). Political system is a set of relevant structures and processes that allocate the social resources based on authority to certain sectors of the society. The output of the system of allocated resources is in the form of decisions and actions that emerge in the ofrm of policy (Jones \& Baumgartner, 2019). The systematic theory has been explicitly and implicitly used by many researchers who seek to analyze and study the causes and outcomes of the public policies (Nagel, 2002). Systematic model expresses the public policy as the output of the system. Theory of policy in the form of a system in the society refers to a set of identifiable institutions and activities that change the needs into reliable decisions that require the support of all social classes. The system theory also refers to the elements of a system that are related with each other. System is able to answer the forces around itself and it handles this in order to sustain itself. Inputs enter the system of policy making in the form of expectations and needs of society and support or refusal of support of citizens inside the system and the output will be the passed policy (Alvani \& Sharifzadeh, 2007). 


\section{8- Political model}

Some thinkers of political sciences have lately struggled to classify the political activities and behaviors based on their relationship with public policies. The result of this action in general is the codification of a set of stages of policy making. In short, from this perspective, one can conceive the process of policy making as a set of political activities in the form of identification of problems, preparation of proposed policies, legalization of policies, implementation of policies and evaluation of policies (Lester \& Stuart, 2003). According to this model, scholars of political sciences should limit their studies as regards the public policy just to these processes (Alvani \& Sharifzadeh, 2007). Political model of policy making allows the scholars to study the mechanism of adoption of decisions and understand the correct method of decision making. But it does not allow it to change and interpret the basis of the public policy (Ewalt, 2001).

\section{Conclusion}

In the contemporary world full of complication and change, the resolution of problems requires enlightened and conscious minds. Man is today encircled by different issues each one of which has faced the future of humanity and his social order with different threats. By adoption of policies, governments struggle to create a change. Policy represents a long term decision that rules in years and is adopted in response to issues. But this answer solves the problems through creation of change. For social problem is aspects of society as to which the people are concerned and seek to change them. If this change overcomes the abnormal situation, and brings the mutual relations of the society and individuals back to normal, it is considered to be a desirable change but if it leads to the decrease of public welfare or intensification of dissatisfaction, it is regarded as an undesirable change. Thus, as we move forward everyday, the policy problems become encountered with further complications and more knowledge and skills in addition to skill and knowledge in the technical and human fields and the administration of organizational affairs are required in the field of economic, social, political and environmental issues. Thus, importance of policy making and study and discussion concerning it is not hidden to anyone.

Reliance on some values, hedonism, materialism, humanism, individualism, rationalism, notion of efficient government as used by the policy makers or unofficial examiners, have challenged the current methods. Particularly, there are some methods that pretend to be able to extract universal laws that are not restricted to time and space. 
This unreal presupposition and as a result, lack of practical conditions of theory, has casted doubts of its validity. The foundations of the philosophical analysis of methodology, application and effects of policy in different domains, stereotypical separation of mind and world and identification of presumptions and realities are among the methodological problems of policy making that have challenged the nature of policy making. If we consider postmodernism to be an intellectual-cultural movement that has influenced all relations of modern man, the science of policy making and processes of public decision making are also under the influence of these paradigms.

Administrative management has experienced many different paradigms and movements in the course of history in the domain of management of societies. These paradigms and movements can be classified in six groups: 1- movement of administrative management, 2- management of traditional affairs; 3- management of modern public affairs; 4- modern administrative management; 5- modern public services; 6- management of religious affairs and religious democracy. Each one of these movements has adopted a specific approach for management of public affairs that can be outlined as follows: (Economic) Managerial Approach: in this approach the knowledge of values is in the hands of the managers and the organization is like a business; the management is like a shopkeeper and the individual who refers to the organization is like a customer. Legal Approach: The scope of action and freedom of action of management of public affairs is determined by the constitution, other mother laws, bills and instructions. Management in administrative sector is in charge of policies that have their origin in every country's constitution. Political Approach: In this approach, organizational structure takes form around the political values, representation, accountability and responsibility. In this approach, representation and decision making based on the public opinions and beneficiaries are important. Professional Approach: Its main doctrine is sthe application of the management of private sector to the administrative sector. The theory of public choice is the manifestation of the behavior of administrative managers in this this approach. Privatization in Iran that has been started in recent years is an endorsement of this approach in administrative sector. Moral Approach: Existing differences in dominant values of the governmental and private sectors are resulted from this approach. Such values as justice, fairness, equality, sensitivity towards the citizens in the governmental sector and efficiency and parsimony are the dominant values of private sector. Religious Approach: In this approach, the servant of God are the lords of the political system. The organizational structure in it 
should be designed based on the principle of people's satisfaction and God's satisfaction and every individual is a servant of God and respected. If an organization makes use of a combination of all aforementioned approaches in policy making in order to achieve its mission and essential goals, this is the clear extension of the theory of collage of rationality and the strategy of Danaeifar et al. (2010) which is a new theory in line with the postmodernism in the process of policy making. Such notions as the criticism of objectivity, irrationalism, superficialism, denial of origin and denial of notions like betterment, development and justice are among the features of the postmodern paradigm that influence the theories of formation of policy. The influence of the aforementioned notions in the process of policy making is conveyed to the mind of every policy maker by such issues as the "Garbage can Model" in policy making, power centers, pressure groups, the mechanism of putting the insignificant issue on the agenda, universal models and the insistence on local models of development and public decision making, pluralism and participation.

\section{References}

Alvani, M. \& Hashemian, M. (2008), Re-reading of Sciences of Policy Making in the Context of Postmodernism: Formation of Policy in Postmodern Field, Journal of Methodology of Human Sciences, 5(6): 99-122.

Alvani, M. \& Sharifzadeh, F. (2007), Process of Public Policy Making. Tehran, Iran: Allama Tabatabaei University Press.

Angello, M. (2001). A postmodern literacy policy analysis. England, Peter Lang Pub.

Brooks, A. \& Lewis, G. (2002), Enhancing policy Models with Explory Analysis, Journal of public sciences, 18(2): 69-80.

Daneshfard, K. (2009), Process of Public Policy Making, Islamic Azad University of Sciences and Researches, First Edition, 17(5): 311-325.

Dye, T. (2002), Understanding public policy, New Jersey, USA: Prentice Hall.

Ewalt, J. (2001), Theories of governance and new public management: Links to understanding welfare policy implementation, prepared for presentation at the Annual conference of the American Society for public Administration, 101-112.

Farahani, M. (2004), Postmodernism and Education, Iran: Abizh Press..

Gerston, L. (2017). Making process and principles. England: M. E. Sharpe.

Gupta, D. (2001). Analyzing publicy. Concepts, Tools, and Techniques. England: CQ 
press.

Guseh, J. \& Clayton, M. (2004), Quality and complexity- reasons form English Higher Education, International Journal of Quality \& Reliability Management, 16(9): 171-186.

Howlett, M. \& Ramesh, M. (2003). Studying public policy: policy cycles and policy subsystems. USA: Oxford University Press, USA.

Jones, B. \& Baumgartner, F. (2019). Model of choice for public policy, Journal of public Administration Research and Theory, 15(1): 63-77.

King, J. \& Kraemer, K. (2007). Models, facts and the policy process The political Ecology of Estimated Truth. Center for Research on information systems and Organization (CRITO), 6(3): 48-60.

Lester, J. \& Stuart J. (2003), Process of Public Policy Making, An Evolutionary Approach. Iran: Savalan Press.

Nagel, S. (2002). Policy Evaluation; Beyond the cutting Edge. USA: Nova Science Pub.

Qolipur, R. (2010). Process of Public Policy Making in Iran. Tehran, Iran: Iranian Parliament Research Center.

Qolipur, R. (2018), Organizational Decision Making and Process of Public Policy Making, SAMT, 11(2): 90-104.

Simon, H. (2019). Administative Behaviour. London; Macmillan

Vahid, M. \& Qalchi, H. (2007). Methods of Public Policy Making, Journal of Politics, Faculty of Law and Political Sciences, 29(1): 140-153.

Vahid, M. (2001). An Introduction to Public Policy Making, Journal of Faculty of Law and Political Sciences, 52(3): 23-40.

Vahid, M. (2006), Democracy in the Mirror of Public Policy Making, Journal of Farhange Andisheh, 18(1): 840-853. 